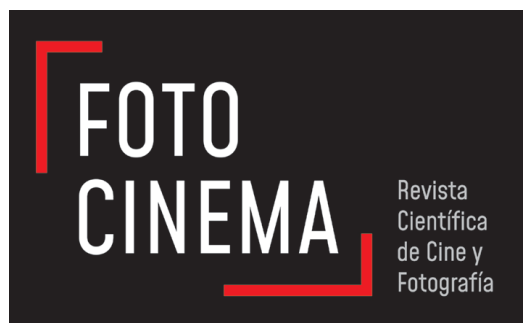

FOTOCINEMA, nº 22 (2021) || E-ISSN: 2172-0150

\title{
Larga vida a las actualidades. La difusión de imágenes del pasado en los archivos en línea
}

\section{Long live newsreels. The dissemination of actuality films in online archives}

\author{
Ana Filipa Martins \\ Universidade do Algarve, Portugal \\ fcerolm@ualg.pt | https://orcid.org/oooo-0002-9732-5797 \\ Olivia Novoa Fernández \\ Universidade do Algarve, Portugal \\ onfernandez@ualg.pt | https://orcid.org/oooo-0002-2682-1195 \\ Ignacio Aguaded \\ Universidad de Huelva, España \\ aguaded@uhu.es | https://orcid.org/o0oo-0002-0229-1118
}

\begin{abstract}
Resumen:
Durante algunas décadas, el reconocimiento del valor de las actualidades cinematográficas y su discusión como registro del pasado estuvieron circunscritos al ámbito archivístico, histórico y televisivo. Apreciados sobre todo por su valor patrimonial y por la curiosidad que suscitan, gracias a la digitalización, estos filmes alcanzan nuevos públicos a través de su divulgación en sitios web, y redes sociales, de diversa naturaleza y con propósitos variados. Con el fin de discutir estos nuevos contextos en línea, proponemos una reflexión sobre las formas de presentación y valoración de dichos recursos fílmicos en archivos de carácter público y comercial. Basándonos en una ficha descriptiva y en una serie de indicadores sobre el acceso a la información, la interacción, el uso de las redes sociales y la contextualización de contenidos, analizamos los sitios web de Gaumont Pathé Archives, British Pathé, Archivo Histórico NO-DO y Archivio Luce. Partimos de la hipótesis de que los extintos noticiarios cinematográficos, en cuanto género precursor del infoentretenimiento audiovisual, sobreviven a la luz de nuevas lecturas, estrategias y usos, con implicaciones para la memoria y la literacía mediática.
\end{abstract}

\begin{abstract}
:
For some decades, the recognition of the value of actuality films and its discussion as a record of the past was limited to the archival, historical and audiovisual production fields. Arousing interest mainly for their memorial or curious nature, thanks to digitalisation, these films reach new audiences through their dissemination on websites and social networks, of different natures and for various purposes. Taking as our starting point an interest in discussing these new online contexts, we propose a reflection on the forms of presentation and assessment of these images in public and commercial archives. Based on a descriptive sheet and a series of indicators on access to information, interaction, the use of social networks and the contextualisation of contents, we analyse the websites of Gaumont Pathé Archives, British Pathé, Archivo Histórico NO-DO and Archivio Luce. We assume that the extinct newsreels, as a precursor genre of audiovisual infotainment, survive in the light of new readings, strategies and uses, with implications for memory and media literacy.
\end{abstract}

Palabras clave: Noticiarios cinematográficos; archivos online; memoria audiovisual; medios digitales; infoentretenimiento; alfabetización mediática.

Keywords: Newsreels; online archives; audiovisual memory; digital media; infotainment; media literacy. 


\section{Introducción}

Las actualidades figuran en la historia del cine asociadas sobre todo a su etapa primigenia, a ese momento fundacional en el que las primeras atracciones deleitaron a un público curioso y fascinado ante las demostraciones de los dispositivos pioneros de exhibición cinematográfica. Comenzaron por consistir en la recolección de pequeños aspectos de la vida cotidiana y posteriormente se fueron consolidando en forma de noticiarios que se proyectaban en salas específicas o antes del largometraje (Aubert, 1996; Baechlin \& Muller-Strauss, 1952; Chambers, Jönsson \& Winkel, 2018; Paz \& Montero, 1999; Pontecorvo, 1983). Las actualidades cinematográficas, convertidas en noticiario, newsreel, o revista, cinemagazine, de Pathé, de Fox Movietone, Paramount, o de Universal, fueron una de las fuentes más populares de información y entretenimiento durante la primera mitad del siglo XX. Estas productoras dominantes convivieron durante décadas con otras empresas de ámbito nacional, tanto de índole comercial privado como de producción estatal, surtiendo las carteleras de los cines en muchos países, en todos los continentes, de Asia a América, hasta su desaparición entre finales de los años 80 e inicios de los 90 (Baechlin \& Muller-Strauss, 1952, entre otros).

En España y Portugal existieron ejemplos propios de producción de actualidades y noticiarios cinematográficos. En el primer caso, aunque hubo otros, destaca el NO-DO - Noticiarios y Documentales -, producido entre 1943 y 1981, de carácter exclusivo y proyección obligatoria, puso fin a la exhibición de otros títulos comerciales y fue diseñado como un vehículo para la propaganda franquista (Paz \& Montero, 1999; Rodríguez Mateos, 2008; Tranche \& Sánchez-Biosca, 2006). En Portugal, las revistas de actualidades del Estado Novo (1933-1974), Jornal Português (1938-1951) e Imagens de Portugal (1953-1970), convivieron con una producción y exhibición variada de noticiarios cinematográficos, algunos más informativos desarrollados por periódicos nacionales o con la colaboración de estos, junto con otros de carácter más comercial (Braga, 2005; Matos-Cruz, 1989; Piçarra, 2006), cuya 
proyección perduró hasta finales de los años 80 . Si ampliamos nuestra mirada a otros contextos, podemos mencionar casos internacionalmente reconocidos e investigados como el de las atualidades de Vertov (MacKay, 2018), las francesas (Huret, 1984; Sorlin, 2004), las alemanas (Ferro, 1993; Kracauer, 1943; Lehnert, 2018, 2020) y las británicas (Hiley \& McKernan, 2001; McKernan, 1992, 2017), el noticiario del Instituto Nazionale Luce (Coronado Ruiz, 2016; Sorlin, 1994), el Noticiero ICAIC Latinoamericano (Johnson, 2013; Shefer, 2016) o el Newsreel norteamericano (Nichols, 1972, 1978; Shefer, 2016), entre otros.

Tras el cese de su exhibición, el material fílmico y documental de este legado cinematográfico conoció destinos diferentes, dependiendo de su naturaleza pública o privada. En el caso español y portugués, se encuentra depositado en los archivos públicos gestionados por sus respectivas instituciones, como Filmoteca Española -y las restantes filmotecas españolas - o Cinemateca Portuguesa. En otros casos, los originales son custodiados y explotados por sus productoras o por otras instituciones que los han adquirido.

En 1993, en un simposio celebrado en Noruega durante el 49. ${ }^{\circ}$ Congreso de la Federación Internacional de Archivos Fílmicos (FIAF), se discutía la situación con respecto al estado de conservación de dicho patrimonio. Aquel simposio fue un momento determinante para reafirmar la importancia de su preservación, estudio y divulgación, informando de diversas iniciativas llevadas a cabo por instituciones y empresas (Smither \& Klaue, 1993; Martins, 2020), que pasarían en los años siguientes por la digitalización de los archivos (FIAF, 2009). Otro momento importante fue la difusión, en 2014, del archivo digital de British Pathé en YouTube (Müller, 2018; Kaye, 2018; Shpolberg, 2014). No se trató de un caso aislado. Años antes, habían sido creados otros sitios web en los que las colecciones digitalizadas de noticiarios se iban volcando para consulta gratuita o para fines comerciales, como los de Gaumont y Pathé, que tras su fusión en 2003, permiten desde 2009 el visionado en línea de su colección.

Desde instituciones como la Unesco o la Unión Europea se ha incentivado la preservación de los archivos fílmicos, mediante recomendaciones, apoyos 
económicos o reconocimientos, que promueven la catalogación y conservación de sus fondos', aunque todavía resta solventar otros problemas como los relacionados con el tratamiento documental o la difusión pública al implementar la digitalización y las nuevas tecnologías (Cuadra de la, 2005; Domínguez Delgado \& López Hernández, 2017b; Torrado Morales, 2005). A medida que el proceso de digitalización ha ido evolucionando, su alcance se ha extendido hasta las redes sociales, de manera que algunos archivos y bancos de imágenes en línea utilizan, en mayor o menor medida, Facebook, YouTube, Instagram o Twitter para divulgar el patrimonio relacionado con las actualidades.

Teniendo en cuenta las cuestiones que implican la digitalización y la difusión de archivos fílmicos en línea (Cuadra de la, 2005; Domínguez Delgado \& López Hernández, 2016, 2017a, 2017b; Johnson, 2013; Kaye, 2018; Lobo, Ramos \& Antunes, 2020; Morettin, 2014; Müller, 2018; Shpolberg, 2014; Torrado Morales, 2005, 2007; entre otros), este artículo pretende contribuir a la sistematización del análisis del patrimonio cinematográfico en la web, planteando una revisión del estado actual de los archivos de Gaumont Pathé, British Pathé, NO-DO y Luce.

\section{Marco teórico}

Al igual que sucede en muchas otras áreas, las instituciones públicas encargadas de preservar el patrimonio fílmico, así como los bancos de imágenes comerciales, se enfrentan a los retos de una "nueva mnemotécnica", es decir, una extensión de la memoria basada en los códigos de la era digital, que a su vez genera contenidos que pueden ser interpretados como lugares de

\footnotetext{
1 Los negativos originales del Noticiero del Instituto Cubano de Arte e Industria Cinematográficos (ICAIC) y los noticiarios y fotografías del Istituto Nazionale LUCE están inscritos en el Registro de la Memoria del Mundo de la Unesco desde 2009 y 2013 respectivamente. La Unión Europea financia el portal European Film Gateway que permite el acceso a varios contenidos históricos, entre ellos, actualidades que forman parte de los fondos de varias entidades europeas. Contribuyen para esta red Filmoteca Española, Instituto Luce Cinecittà, Archives françaises du film du CNC y Cinemateca Portuguesa- Museu do Cinema, entre otras.
} 
memoria y que importa también preservar (Cádima, 2020, pp. 195-197). En este paso hacia la réplica digital, que les ofrece una preservación sin límites, dicha "descorporeización" del material salvaguardado plantea una serie de cuestiones, tales como la añoranza que despierta la amenaza de su desaparición o la aproximación de las imágenes al presente mediante formas tecnológicas que las familiaricen con la actualidad (Sánchez-Biosca, 2015, pp. 221-222).

Tal vez la primera de dichas cuestiones pueda explicar que la respuesta académica ante la disponibilidad de los archivos no haya sido la esperada, según vienen señalando algunos investigadores en contextos en los que la digitalización ha avanzado más (Kaye, 2018; McKernan, 2009), como si ello conllevase una pérdida de la "emoción de archivo" descrita por Sánchez-Biosca (2015). Sin embargo, Internet, entre sus múltiples facetas, puede concebirse también como un ingente archivo digital automatizado de metadatos, susceptible entonces de despertar sus propias emociones, aunque quizá haya que esperar al futuro.

La segunda cuestión nos invita a reflexionar sobre cómo influyen los nuevos medios tecnológicos en las formas de actualización de estos documentos fílmicos, teniendo en cuenta que ya ha sido señalada una desintegración de los noticiarios y revistas de actualidades a "mero contenido" cuando son volcados en plataformas como YouTube o reutilizados como evidencias históricas en filmes de archivo (Kaye, 2018, p. 297; Sieber, 2016, p. 24). Nos interesa comprender cómo estos recursos fílmicos e históricos son presentados, promovidos y difundidos en línea, así como analizar qué aspectos se valoran al contextualizarlos y confrontarlos con el presente. Partimos de la perspectiva de que la capacidad de atribuirles un contexto, no solo actual sino también histórico, es una competencia mediática que también puede ser fomentada a través de estos sitios web, al entenderlos como extensiones de las memorias construidas por el cine durante el siglo pasado (Lusnich \& Morettin, 2020; Reia-Baptista, 2010). 


\section{Aspectos metodológicos y corpus de análisis}

Haciendo un paralelismo con la conocida dicotomía nativo-inmigrante digital, una primera distinción nos lleva a señalar que nuestro objeto de estudio se situaría en una zona fronteriza, pues si bien se trata de instituciones y objetos materiales que han migrado al entorno web, también pretendemos observar características propias de dicho entorno, como la multimedialidad, la hipertextualidad, la interactividad, la actualización constante de información y la personalización (Eiroa \& Barranquero, 2017, p. 156). Por ello, nos decantamos por una metodología cualitativa basada en la observación en línea que adapte los métodos tradicionales de investigación al contexto digital (Eiroa \& Barranquero, 2017, p. 169).

Nuestro estudio pretende describir y comparar los diferentes sitios web mediante los que los archivos y bancos de imágenes divulgan los filmes de actualidades en Internet. Para esta aproximación comparativa diseñamos una ficha técnica descriptiva (v. T. 1), basada en propuestas metodológicas para el análisis de medios digitales y cibermedios, en la que incluimos algunos indicadores que responden a nuestros objetivos (Codina et al., 2014; Cuadra de la, 2005; Eiroa \& Barranquero, 2017, pp. 158-163; Rodríguez Martínez, Codina, \& Pedraza Jiménez, 2012; Torrado Morales, 2005, 2007; entre otros). Partimos de nuestra experiencia en la investigación de contenidos relacionados con las actualidades fílmicas en el contexto ibérico (Martins, 2020; Novoa Fernández, 2019) para relacionarla con la perspectiva del usuario de estos sitios web, por lo que prestaremos especial atención a los parámetros sobre el acceso a la información, la interacción con el usuario y el uso de las redes, para relacionarlos con la contextualización de contenidos fílmicos. Partiendo de la hipótesis de que existe un conjunto de diferencias en las formas de presentación de actualidades entre los sitios web y sus redes sociales, observamos cómo funciona el uso de descripciones, hiperenlaces, etiquetas, galerías de imágenes, comentarios, botones de favoritos o compartir a la hora de valorar estos contenidos fílmicos y de tomar contacto con ellos. Consideramos que estas herramientas y funcionalidades podrían constituir 
formas para atribuirles valor, a la vez que inspirarían nuevos modelos de actualización influenciados por las redes sociales.

\begin{tabular}{|c|c|}
\hline \multicolumn{2}{|c|}{ Análisis de sitios web de archivos de actualidades cinematográficas } \\
\hline Identificación & $\begin{array}{l}\text { Nombre. } \\
\text { URL. } \\
\text { País. } \\
\text { Ubicación y fecha de creación (versiones y cambios a lo } \\
\text { largo de su existencia). } \\
\text { Naturaleza del archivo (privado, comercial, público, } \\
\text { subvencionado). }\end{array}$ \\
\hline Características generales & $\begin{array}{l}\text { Secciones y organización. } \\
\text { Servicios ofrecidos (consultas, bases de datos, } \\
\text { documentación, divulgación, noticias, adquisición de } \\
\text { licencias, venta, entretenimiento, creación de } \\
\text { comunidades). }\end{array}$ \\
\hline Contenidos fílmicos & $\begin{array}{l}\text { Disponibilidad íntegra o parcial de las actualidades. } \\
\text { Organización. Colecciones promovidas en la página de } \\
\text { inicio, en el resto de páginas y en las diversas secciones. }\end{array}$ \\
\hline $\begin{array}{l}\text { Acceso a la información y } \\
\text { arquitectura de los } \\
\text { contenidos }\end{array}$ & $\begin{array}{l}\text { Formas de recuperación de los contenidos fílmicos. } \\
\text { Acesso abierto, mediante registro o mixto. } \\
\text { Tipología de los buscadores. } \\
\text { Secciones temáticas, carpetas, timelines, galerías, } \\
\text { etiquetado, noticias, archivo propio... }\end{array}$ \\
\hline Interacción & $\begin{array}{l}\text { Definición del público objetivo y formas de interacción } \\
\text { con el usuario. } \\
\text { Idiomas disponibles. } \\
\text { Comunicación y contacto con el usuario. } \\
\text { Registro, suscripción, personalización de la interfaz } \\
\text { según los intereses del usuario, publicación de } \\
\text { comentarios, posibilidad de compartir el contenido, } \\
\text { interacción con otros usuarios... }\end{array}$ \\
\hline $\begin{array}{l}\text { Contextualización de los } \\
\text { contenidos fílmicos. }\end{array}$ & $\begin{array}{l}\text { Presentación y documentación de las actualidades y } \\
\text { noticiarios. } \\
\text { Sinopsis, resúmenes, etiquetado, fechas, temas, } \\
\text { acontecimientos, personalidades, datos técnicos, datos } \\
\text { de catalogación, documentos fílmicos... } \\
\text { Formas de relación con la actualidad (efemérides o } \\
\text { acontecimientos). }\end{array}$ \\
\hline $\begin{array}{lll}\begin{array}{l}\text { Plataformas } \\
\text { sociales. }\end{array} & \text { y } & \text { redes } \\
\end{array}$ & $\begin{array}{l}\text { Presencia en las redes sociales. } \\
\text { Uso de las funcionalidades de las redes sociales. } \\
\text { Canal de YouTube. } \\
\text { Enlace a redes sociales o a plataformas. } \\
\text { Posibilidad de compartir contenidos. }\end{array}$ \\
\hline
\end{tabular}

T1. Análisis de sitios web de archivos de actualidades cinematográficas

Para exponer nuestro análisis, optamos por definir un corpus limitado, aunque suficientemente diverso, de modo que proporcione una perspectiva amplia y al mismo tiempo comparativa. Basándonos en criterios como la variedad 
geográfica, histórica y su presencia en diferentes contextos en línea, seleccionamos dos bancos comerciales y dos archivos de patrimonio público europeos: Gaumont Pathé Archives², British Pathé3, Archivo Histórico NO$\mathrm{DO}^{4}$ y Archivio Luce5.

Puesto que no consideramos que sus sitios web divulguen fundamentalmente actualidades o noticiarios, excluimos otros casos conocidos: ya sean los de instituciones públicas como la plataforma del Institut National de l' Audiovisuel francés ${ }^{6}$, donde se encuentra disponible el Noticiero ICAIC latinoamericano, o el de la Cinemateca Portuguesa7, en el que se puede visionar algunas actualidades lusas; ya sean los que gestionan empresas privadas comerciales como la americana Getty Images $^{8}$, que comercializa imágenes del catálogo de Sherman Grinberg9, entre otras. Y también la pionera News on Screen ${ }^{10}$, incorporada en el portal Learning on Screen, del British Universities Film and Video Council, dado que por sí misma constituye un caso de estudio aparte debido a la labor desempeñada en el ámbito académico y educativo (Kaye, 2018). En cualquier caso, con relación a los ejemplos estudiados mencionaremos también otros modelos de divulgación que ilustran la presencia de este patrimonio en Internet.

\section{De sitios web a plataformas digitales, diferentes vías de acesso a los contenidos}

En todos los archivos analizados el sitio web funciona como una invitación a explorar un conjunto diversificado de contenidos fílmicos, cuya consulta puede hacerse en línea o in situ. Por otro lado, estas entidades realizan una serie de servicios tales como la digitalización del acervo fílmico,

2 https://gparchives.com

3 https://www.britishpathe.com

4 https://www.rtve.es/filmoteca/no-do/

5 https://www.archivioluce.com

6 https://www.ina.fr

7 https://www.cinemateca.pt

8 https://www.gettyimages.com

9 https://www.shermangrinberg.com

${ }_{10} \mathrm{http://bufvc.ac.uk/newsonscreen}$ 
documentación y organización en bases de datos; la promoción del patrimonio apoyando actividades o participando en proyectos; la dinamización y actualización de contenidos a través de artículos o noticias; la venta de productos o licencias de filmes, e incluso, la oferta de entretenimiento a través de nuevos formatos. Todas estas actividades o servicios están presentes en mayor o menor medida en sus páginas web, que funcionan así como portales, repositorios, bases de datos o medios de comunicación, presentando un aspecto híbrido que se va aproximando al de las plataformas, más centradas en el usuario y en promover la "comunicación, entretenimiento y creación de comunidades” (Túñez López \& Chillón Álvarez, 2010, p. 129).

\subsection{GP archives: un archivo del siglo $\mathrm{XX}$}

El patrimonio de aquel que es conocido como el noticiario de actualidades más antiguo, el Pathé Journal creado en 1909, se encuentra diponible en el sitio oficial de Gaumont Pathé Archives. Este archivo comercial, resultante de la unión de los fondos de las dos históricas empresas, comprende diversas colecciones de actualidades, presentadas como "La Mémoire du siècle depuis 1895”, y también documentales, películas amateur y otras imágenes, que componen un acervo de " 250 ooo documents, 17 ooo films documentaires, 14 ooo heures d'archives", tal como aparece destacado en la cabecera de su página de inicio (Gaumont Pathé Archives, s.f.). La colección de actualidades incluye los títulos Eclair Journal, France Actualités, Gaumont Actualités y Pathé Revue, entre otros.

Su sitio web presenta una estructura sencilla, con un menú general fijo en el que se incluye un buscador, un menú desplegable sobre las colecciones, y otras secciones habituales que nos dirigen a sendas páginas con la historia de las productoras, información sobre las tarifas de licencia y contactos. El acceso a los contenidos de actualidades se organiza de dos formas: a través del buscador de la base de datos y mediante la presentación de teasers y dossiers thématiques en el cuerpo de la página de inicio. 
Los teasers están formados por vídeos acompañados de textos que los relacionan con la actualidad o con efemérides, como por ejemplo el inicio del curso escolar en 1960 durante el mes de septiembre. Los dossiers son una galería de imágenes formada por fotogramas relacionados con apartados tan variados como la I Guerra Mundial, la Revolución Rusa, el Tour de Francia o el Festival de Cannes. Ambos funcionan como hiperenlaces y reclamo para el registro en el sitio, indicando que los vídeos se reservan a profesionales del audiovisual.

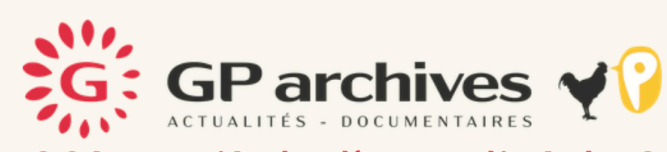

L'histoire du 20ème siècle, l'actualité du 21ème siècle. 250000 documents, 17000 films documentaires, 14000 heures d'archives

Histoire, société, politique, culture, sport, environnement

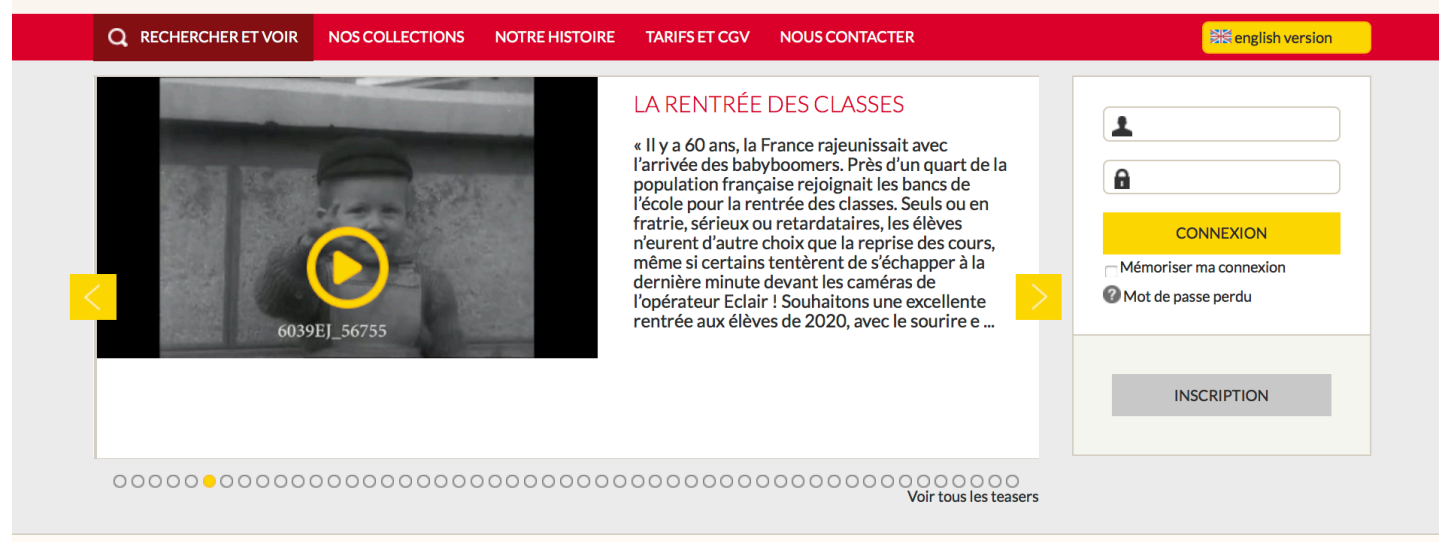

DOSSIERS

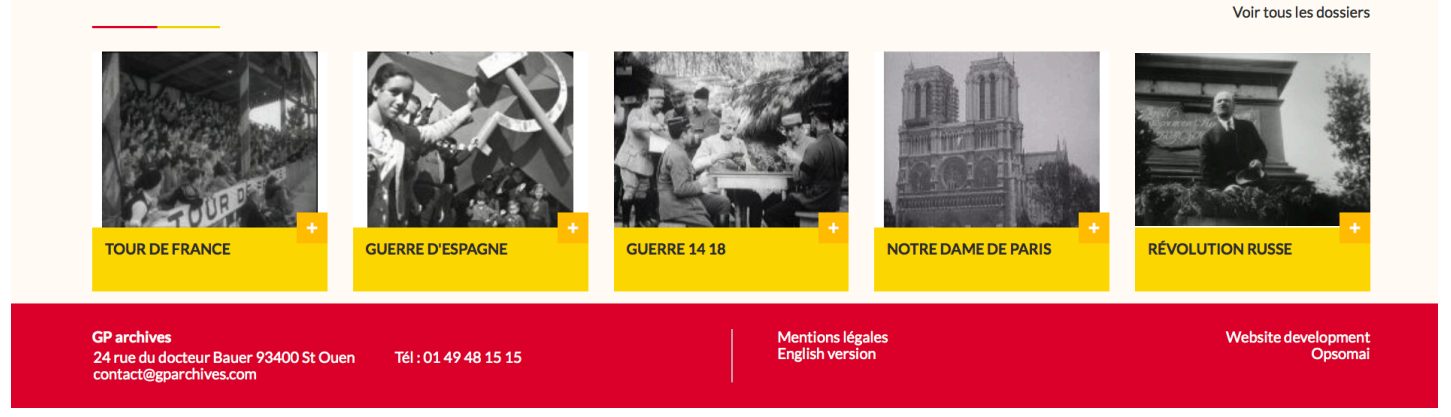

F1. Captura de la página de inicio de GP archives

El buscador utiliza los criterios habituales para filtrar la recuperación de los contenidos, incluyendo otros más específicos como el género y la duración de los clips. Sin necesidad de registrarse, el usuario puede recuperar listas con capturas, que indican la colección, duración, color y sonido. Además, es posible afinar la búsqueda gracias a una indización que organiza las palabras 
clave en personas, lugares, fondos del archivo y períodos. Mediante la creación de la cuenta se accede a los vídeos - por ejemplo, reportajes de noticiarios y revistas cinematográficos, descartes sin editar o documentales-, acompañados de descripciones que incluyen resúmenes más o menos completos, a veces con la transcripción de la voz en off, datos técnicos, palabras clave, hiperenlaces a documentos similares y digitalizaciones de documentos de producción. Asimismo, se puede utilizar un storyboard para navegar por el vídeo y una herramienta para seleccionar las imágenes que se pretendan solicitar para la adquisición de su licencia.
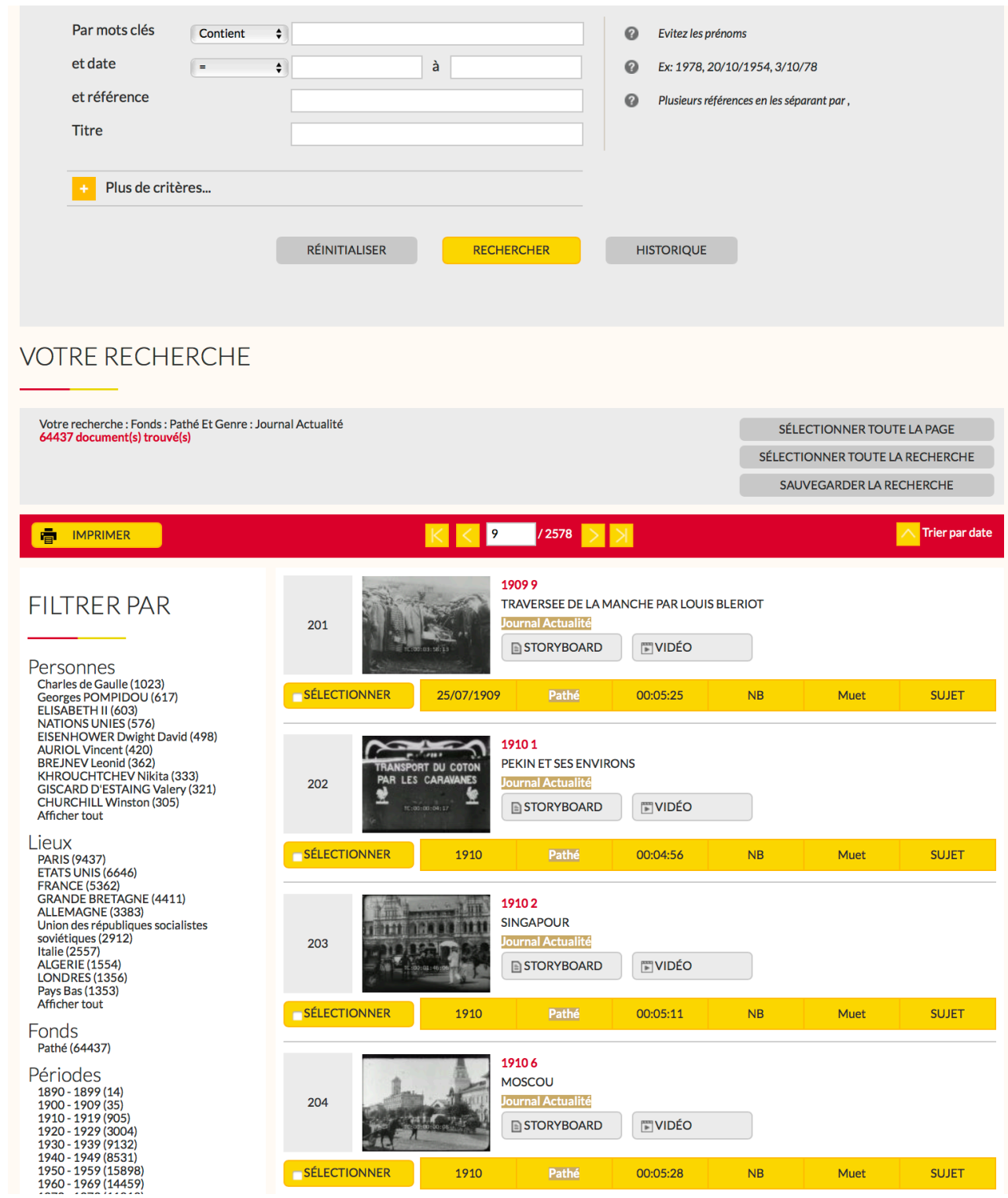

F2. Captura del buscador de GP archives 
En el acceso a los contenidos, este archivo francés es similar a otros bancos privados como el estadounidense Sherman Grinberg, que ofrece las colecciones norteamericanas de Pathé y Paramount. GP Archives constituye un archivo comercial muy completo, organizado de forma que los contenidos sean fáciles de recuperar y dirigido principalmente a profesionales del sector audiovisual. La información sobre los servicios y tarifas se refiere sobre todo a un uso televisivo de las imágenes sin contemplar su consumo para fines privados o de entretenimiento. Su página no presenta enlaces a otras plataformas, aunque la empresa tiene un perfil en Linkedin ${ }^{11}$.

\subsection{El gigante British Pathé y la presencia en las redes sociales}

British Pathé es el mayor archivo comercial en línea y el más presente en los medios sociales. Su legado, que engloba el patrimonio de la Reuters historical collection, incluye otros fondos como los de las filiales británicas de newreels de Gaumont y Paramount. Con más de 200 ooo clips definidos como históricos, constituye un manantial de contenidos que descubrir a través de múltiples itinerarios organizados bajo diferentes formas y objetivos (British Pathé, s.f.).

Situado en la cabecera de todas las páginas se encuentra el buscador, que permite usar filtros siguiendo varios criterios como el color, la disponibilidad para licencia, catalogaciones de los archivos Pathé y Reuters, o categorías genéricas como "Entertainment \& Humour", "Historical figures \& celebrities" o "Religion \& Politics”. Al recuperar la información, además de aplicar más filtros, pueden consultarse listados (Workspaces) sugeridos por la entidad o por otros usuarios.

Los clips de vídeo se presentan acompañados de un sumario breve y de una descripción más o menos detallada junto con datos técnicos, información de catalogación y etiquetas identificadoras que enlazan a documentos similares. Así, es posible recuperar documentos utilizando, por ejemplo, el hiperenlace

${ }^{11}$ https://www.linkedin.com/company/gaumont-path-archives 
de la fecha de edición o los tags, lo cual puede resultar bastante útil tanto para profesionales como para investigadores. Sin embargo, debido a su formato de banco de clips para usos comerciales, es difícil localizar y contextualizar las imágenes dentro de números o ediciones de noticiarios y revistas originales. British Pathé utiliza un reproductor propio y da la posibilidad de recomendar en Facebook, tuitear, utilizar marcadores o enviar por correo la página de cada vídeo.

Registrándose en el sitio, el usuario puede añadir contenidos al Workspace para crear listas privadas o públicas, seguir las de otros usuarios, y también se le invita a publicar comentarios que ofrezcan información sobre los filmes evitando abusos y difamaciones. En general, el registro parece dirigirse más bien a la comunidad de profesionales o para usuarios interesados en comprar contenidos. El archivo promueve la adquisición online de sus productos y servicios (footage sales) ofreciendo diferentes modalidades según los perfiles de los clientes, tales como adquisición de licencias para uso profesional, suscripciones para museos o instituciones educativas, compra de filmes para uso privado o una colección de DVD a la venta en Amazon.

A través del menú fijo se accede a la secciones In the News, Collections y Galeries, entre otras. La primera ofrece la suscripción a una mailing list destinada a periodistas, utilizando como reclamo un vídeo con una selección actualizada de efemérides. Presentada como una vía para explorar el enorme acervo ahorrándose el difícil y lento trabajo de recorrerlo, Collections propone un itinerario guiado en el que los filmes se agrupan en categorías basadas en tres criterios de contenido: temas, lugares y personalidades. Organizadas en apartados como War Collections, Politics \& Political Figures o Country Profiles, incluyen listados con selecciones, algunas de la cuales se presentan en el menú desplegable fijo, tales como las tituladas Churchill: A Life on Film o Russia: Revolution \& Civil War. En las galerías de imágenes encontramos títulos sugerentes y apelativos como "Greatest Olympians of the Twentieth Century" "History's Greatest Replies and Insults" o "Animals Doing Shocking Things", que recogen una selección de fotogramas comentados y con un hiperenalce al clip original, el cual no siempre mantiene una relación directa 
con el asunto. Esta sección incluye sobre todo contenidos sensacionalistas y curiosidades, asuntos típicos de los noticiarios cinematográficos comerciales, en los que primaba el entretenimiento sobre la información, actualizados ahora mediante nuevas fórmulas de presentación basadas en estrategias y narrativas virales que fomentan el clickbait (Martins, Novoa Fernández, Aguaded \& Tavares, 2019).

Parte de estos contenidos se replican en la página de inicio, que presenta hiperenlaces a colecciones y galerías, entradas destacadas del blog, secciones como Today's Anniversary, con una selección de vídeos actualizada diariamente, o Editor's Picks, con las novedades incorporadas al archivo. Además de los botones a Facebook ${ }^{12}$, Twitter ${ }^{13}$, Pinterest ${ }^{14}$, Tumbrl15, Linkedin $^{16}$ e Instagram ${ }^{17}$, redes en las que el archivo está presente, se anuncian contenidos de la plataforma streaming.

British Pathé $T^{18}$ fue lanzado en 2016 como canal de suscripción online y actualizado en 2019 para funcionar en aplicaciones de dispositivos de Apple, Android y Fire TV de Amazon. Dirigido a una audiencia especializada, que la entidad describe como "history buffs, royal watchers, cinema aficionados, and train enthusiasts”, constituye una extensión más para la reutilización de los contenidos, al ofrecer documentales de archivo para entretenimiento.

En la página se echa en falta uno de los iconos, el de YouTube ${ }^{19}$, donde British Pathé posee desde 2009 un canal con más de dos millones de suscriptores, en el que lleva volcando vídeos desde 2014, con cientos de listas de reproducción, alcanzando más de 800 millones de visualizaciones. Uno de los filmes de atualidades más popular, reproducido más de 8 millones de veces, es un reportaje especial, cuya fecha de edición y exhibición son desconocidas, sobre el accidente del dirigible nazi Hindenburg (British Pathé, 2011). Titulado

\footnotetext{
12 https://www.facebook.com/britishpathe

13 https://twitter.com/britishpathe

14 https://tr.pinterest.com/britishpathe

15 https://britishpathe.tumblr.com

16 https://www.linkedin.com/company/british-pathe

17 https://www.instagram.com/britishpathearchive

${ }^{18}$ https://www.britishpathe.tv

19 https://www.youtube.com/c/britishpathe
} 
"Hindenburg Disaster: Real Zeppelin Explosion Footage (1937)" e identificado con los hashtag “\#BritishPathé”, “\#History” y “\#Hindenburg”, un párrafo destaca la autenticidad y espectacularidad de las imágenes. La descripción, hecha en un tono apelativo - "Witness the infamous Hindenberg disaster with this original archive footage of the Nazi airship..." -, en la que se incluyen breves datos informativos como la fecha del desastre y el número de muertos, no deja de ser sino una actualización de los reclamos de los cines de actualidades. Las imágenes compiten ahora con otros vídeos de YouTube, en comparación, menos auténticos, por ser ficticios o recreaciones llenas de efectos especiales, tal como el espectador podría comprobar utilizando el hashtag “\#Hindenburg”. En este caso, los comentarios están desactivados.

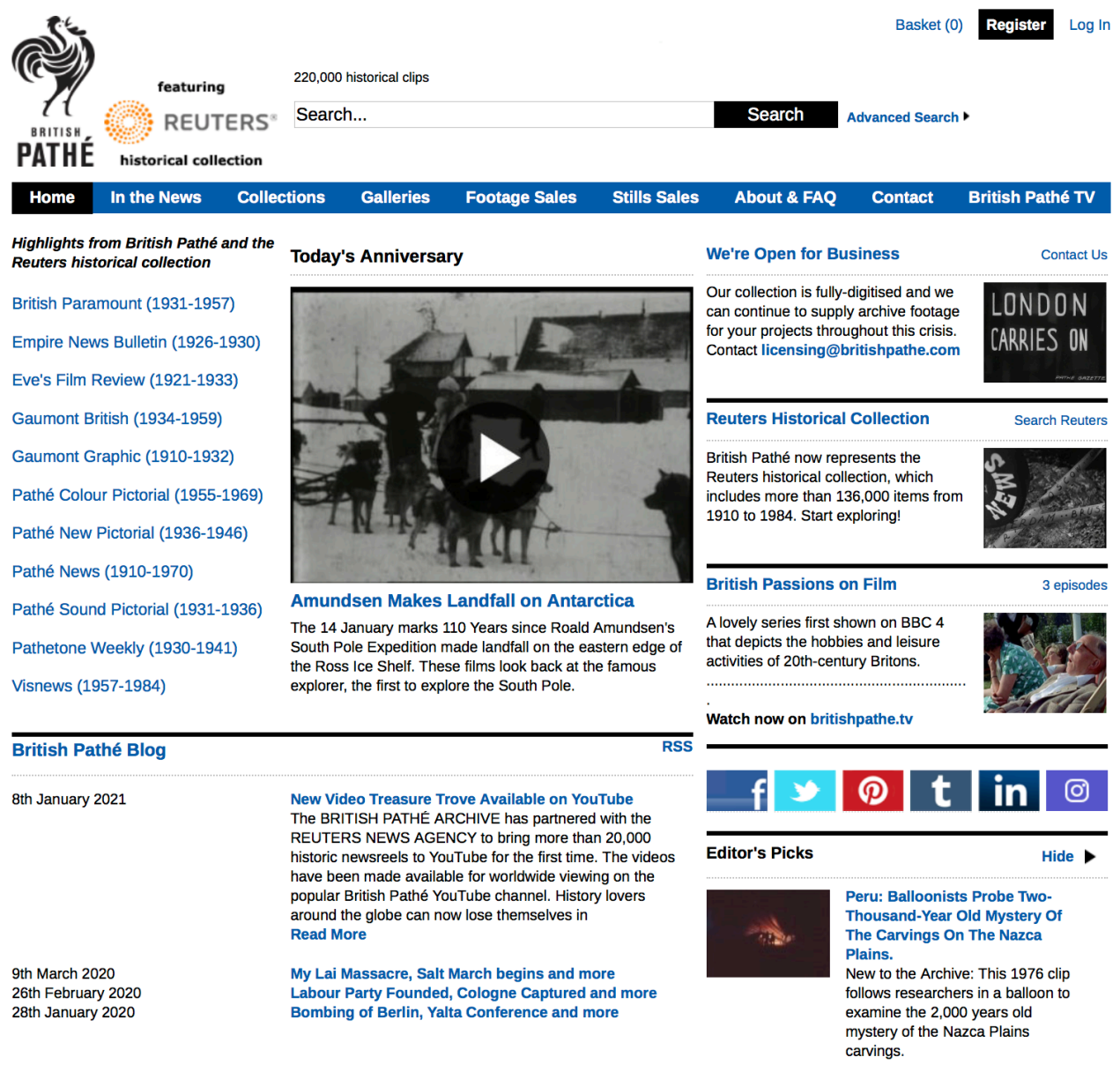

F3. Captura de la página de inicio de British Pathé

Como reza su presentación en este vídeo "British Pathé was at the forefront of cinematic journalism, blending information with entertainment to popular 
effect" y pretende seguir estándolo sugiriéndonos la suscripción a su canal o seguir el enlace al vídeo "Franz Reichelt’s Death Jump off the Eiffel Tower (1912)", si queremos deleitarnos con más desastres capturados por los cazadores de imágenes del siglo pasado. Dirigido a interesados en adquirir la licencia, otro hiperenlace nos conduce a la página del vídeo, donde la ficha da detalles del contenido y tipología de las tomas, avisando incluso de una grafía alternativa -Hindeberg - para recuperar otras imágenes.

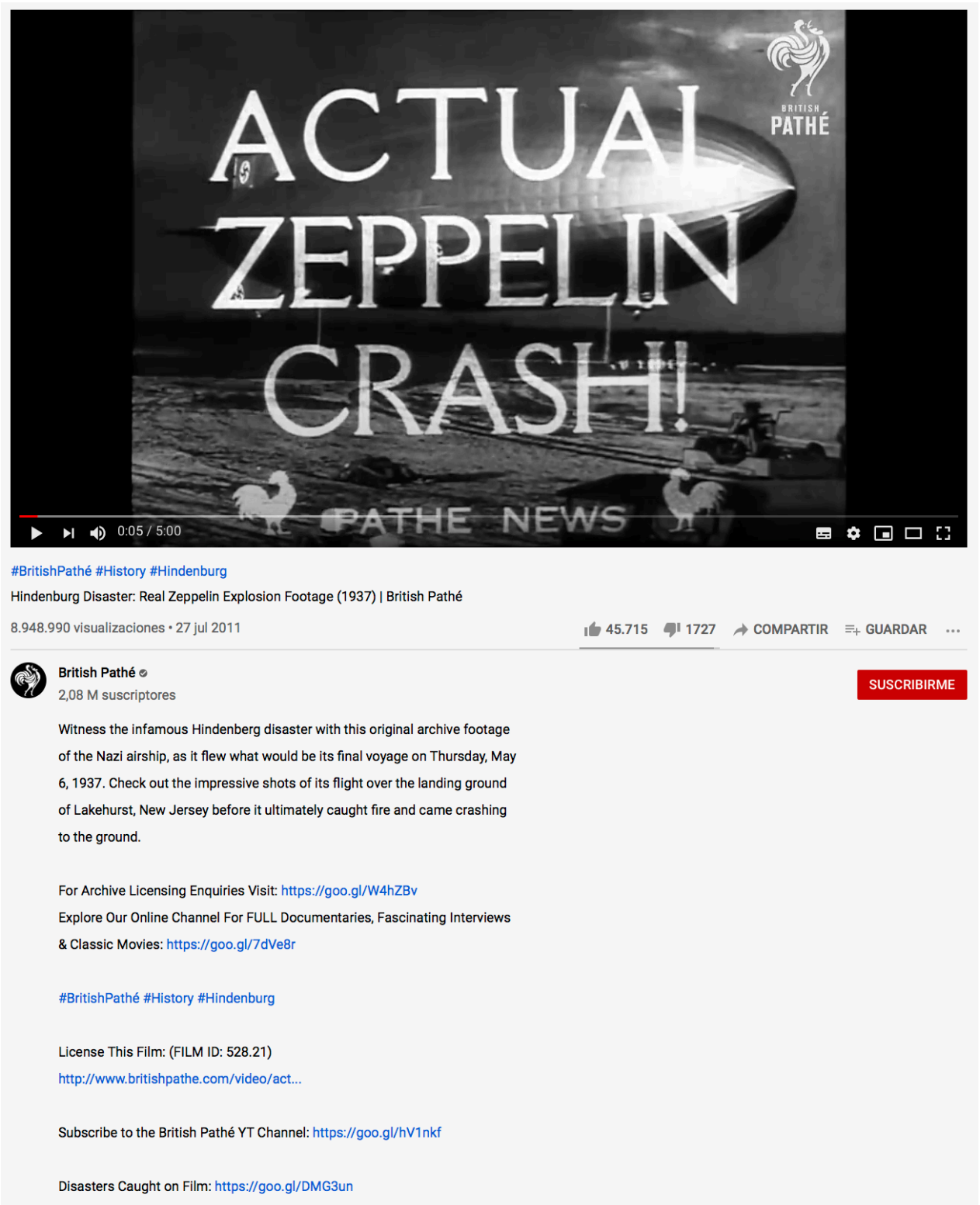

F4. Captura del canal de YouTube de British Pathé 
La disposición de los contenidos confirma que las redes sociales funcionan como extensiones del catálogo en línea, donde en todo momento se invita al usuario a descubrir, comentar, compartir y, claro, a promocionar y adquirir los productos. Esta tendencia de diseminación transmedia, actualizando y dando valor a los contenidos para alcanzar un público más amplio, intenta ser seguida por otras empresas como la productora belga Belgavox ${ }^{20}$, que mantuvo una revista de actualidades hasta 1994, y vuelca sus históricos contenidos en YouTube compartiéndolos en Facebook y en un sitio web de reciente creación.

\subsection{Archivo Histórico NO-DO: patrimonio público en línea}

El archivo histórico del NO-DO se encuentra disponible en su totalidad, desde 2015, en una página de Filmoteca Española alojada en el portal de Radio y Televisión Española, lo cual supuso un paso importante al facilitar el acceso público previsto ya desde la constitución del archivo en la década de los 80 (Tranche \& Sánchez-Biosca, 2006, pp. 73-74). Además de todos los noticiarios de NO-DO, figuran los números de la revistas Imágenes e Imágenes del Deporte, documentales producidos por la entidad y otros fondos procedentes de adquisiciones hechas por el organismo. Dichos fondos componen el Archivo Real (Alfonso XIII) y el Archivo Histórico, compuesto por filmes anteriores o contemporáneos al NO-DO, que la página presenta organizados en secciones como I Guerra Mundial, II Guerra Mundial, o República y Guerra Civil (RTVE \& Filmoteca Española, s.f.).

La página de Filmoteca Española en RTVE, además de NO-DO, incluye otros géneros accesibles a través del menú general, que divide en películas, cortometrajes y documentales. Estas páginas contienen una miscelánea de los fondos de la filmoteca y del canal televisivo, incluyendo también clips de actualidades del período mudo. En el cuerpo, tres galerías de imágenes interactivas destacan los contenidos de NO-DO, mostrando números coincidentes con el mes de acceso a la página, o los noticiarios más vistos,

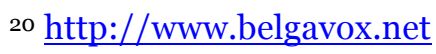


donde el primer puesto es para su edición inaugural, titulada originalmente Introducción al primer noticiario español.

En el menú de NO-DO se pueden explorar las colecciones "respetando la estructura clásica y original del archivo", tal como se explica en la presentación de sus contenidos, accesible mediante un enlace a pie de página. La conservación de la estructura de las colecciones, junto con la opción de volcar los noticiarios de manera íntegra, nos parece uno de los puntos fuertes del archivo NO-DO, sobre todo desde el punto de vista de la investigación. Otro vínculo en el pie, denominado "Para investigadores", dirige al usuario a una página con algunas indicaciones para la consulta gratuita en las instalaciones e informaciones sobre la adquisición de duplicados o material para fines académicos, educativos, institucionales y comerciales. Cabe señalar que Filmoteca Española es la propietaria del archivo de NO-DO, mientras que RTVE mantiene también derechos para su explotación (Tranche \& SánchezBiosca, 2006, p. 73). Para contrarrestar los problemas de recuperación de información al no seguir una organización cronológica o temática de las colecciones, el buscador, bastante simple, utiliza filtros por mes, año y género. Además, los noticiarios pueden recuperarse utilizando un rango de fechas o el número de edición.

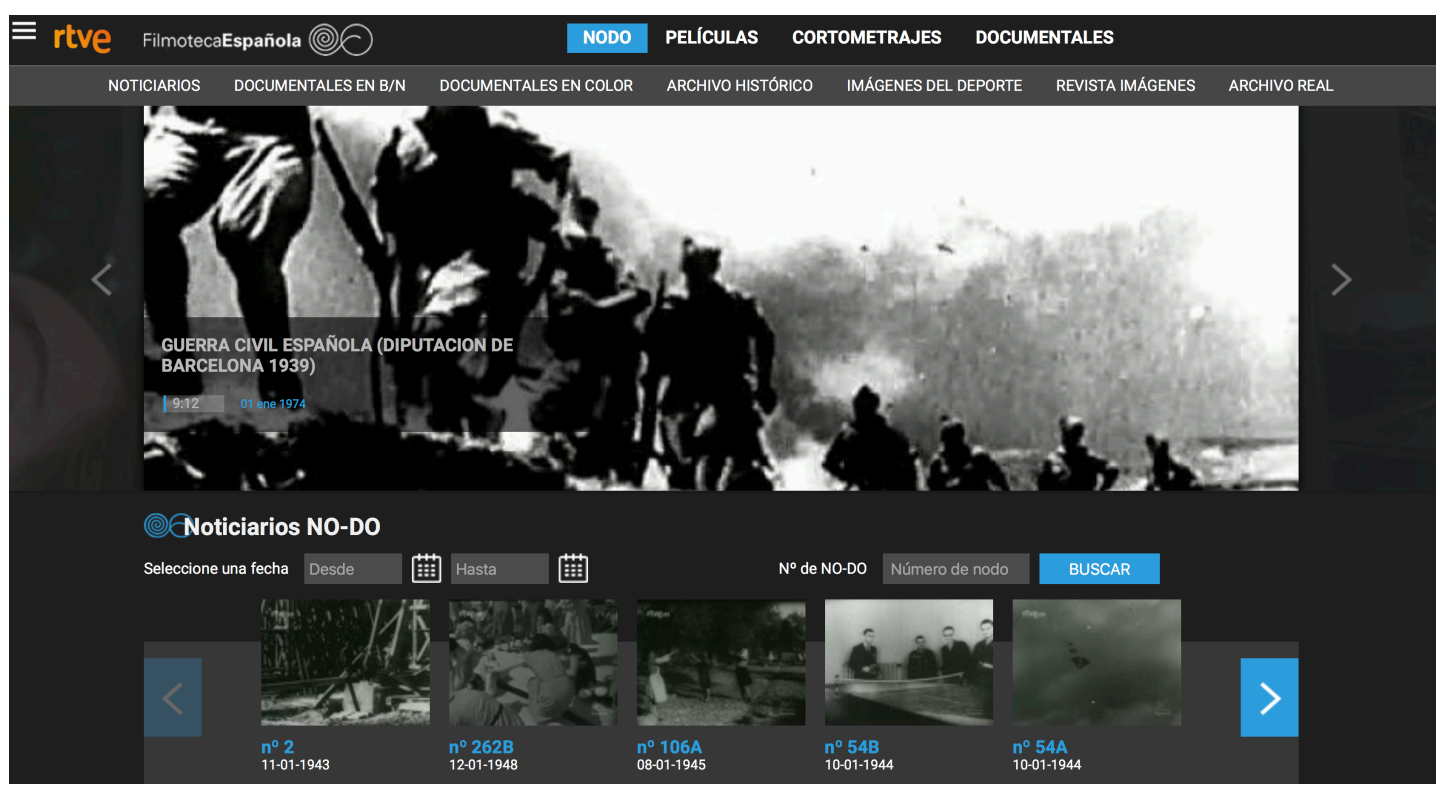

F5. Captura de la página de inicio del Archivo Histórico NO-DO 
El cuerpo de la página de inicio de NO-DO está formado por varias cajas interactivas con galerías de imágenes y frames organizados por colecciones que enlazan a los documentos audiovisuales respectivos. Utilizando el reproductor de RTVE, se puede copiar el enlace del vídeo, compartirlo en Facebook y Twitter, o insertarlo usando el código embed, en algunos casos. Las ediciciones de noticiarios se presentan acompañadas de un breve resumen basado en los contenidos, de un listado con "puntos de interés" indicando el código de tiempo y de un enlace donde se puede descargar el programa de mano de la época.

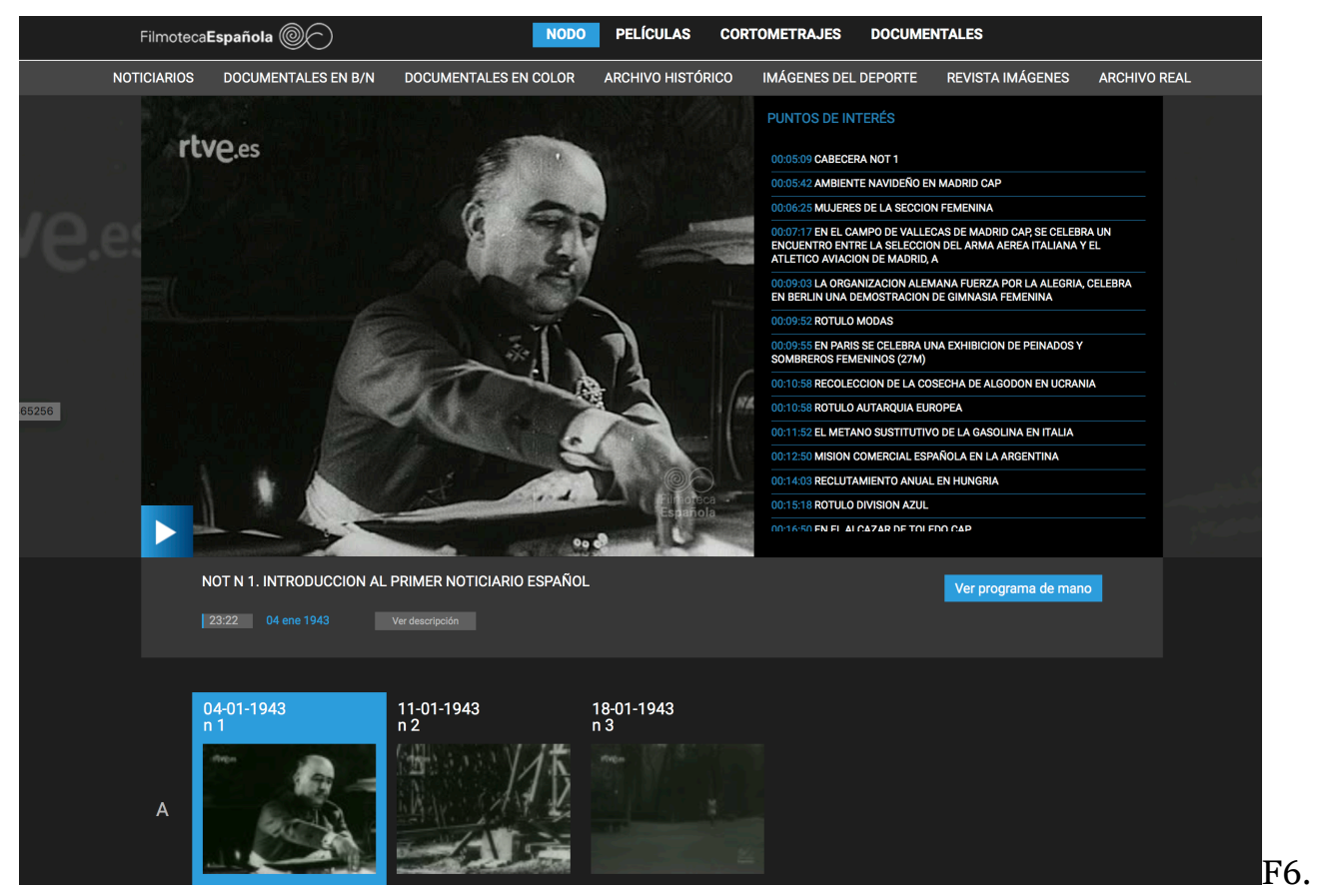

Captura de una página del Archivo Histórico NO-DO. Primera edición del noticiario

El Archivo Histórico NO-DO no está presente en las redes sociales, aunque ambas instituciones sí lo están, dado que el archivo de RTVE tiene un canal en YouTube $^{21}$ y una página de Facebook ${ }^{22}$, y Filmoteca Española ${ }^{23}$ utiliza Vimeo, Facebook, Twitter e Instagram.

El trabajo de divulgación de NO-DO está al mismo nivel que las iniciativas de visionado en línea llevadas a cabo por archivos y filmotecas de otros países,

${ }^{21}$ https://www.youtube.com/c/RTVEArchivo

22 https://www.facebook.com/archivortve

23 http://www.culturaydeporte.gob.es/cultura/areas/cine/mc/fe/portada.html 
como es el caso de la Cinemateca Digital portuguesa, que incluye actualidades de inicios del siglo $\mathrm{XX}$, algunas ediciones de revistas cinematográficas del Estado Novo o actualidades de las excolonias portuguesas, entre otras. Muchos de estos contenidos se encuentran también accesibles a través el portal European Film Gateway ${ }^{24}$ que forma parte de la red Europeana.

\subsection{Archivio Storico Luce: las potencialidades del archivo digital}

Archivio Storico Luce, perteneciente al instituto público Luce-Cinecittà, permite consultar en línea "Un vasto patrimonio composto da fondi cinematografici, fotografici e documentari” entre el que se encuentran las series de Cinegiornali Luce, Cinegiornale UFA y Caleidoscopio CIAC, y otros noticiarios y revistas cinematográficos italianos (Istituto Luce-Cinecittà, s.f.). La web, renovada en 2018, posee características de los archivos comerciales asociadas a su misión de servicio público, plasmada sobre todo en la presentación de proyectos y portales temáticos realizados en colaboración con otras instituciones.

El menú horizontal desplegable de la página propone múltiples itinerarios que el usuario puede escoger y personalizar. La sección Esplora funciona como una antesala a partir de la cual podemos definir nuestro recorrido. Es posible visitar el archivo cinematográfico siguiendo criterios como el tipo de documento, descubriendo las colecciones de noticiarios, documentales, descartes o nuevas adquisiciones, todas ellas presentadas con una explicación del tipo de material que vamos a encontrar y con la indicación del número de documentos. Asimismo, el archivo fotográfico se presenta organizado por colecciones descritas y datadas.

Podemos también realizar recorridos temáticos organizados por múltiples categorías, tales como “Arte e Cultura”, "Costume” o “Geografía”, recuperando los contenidos a partir de las mismas, o utilizando subcategorías que funcionan como etiquetas. Una vez obtenidas las listas de documentos, permite también afinar la búsqueda mediante varios filtros referidos al archivo, al tipo de documento, a las colecciones o al contenido según

24 https://www.europeanfilmgateway.eu 
personalidades, lugares o temas. Tal como vimos para los restantes archivos también se puede acceder a la base de datos a través del buscador, utilizando diversos criterios como géneros, rangos de fechas o contenido. Además, a pie de página se incluye un buscador interno del sitio web y un enlace a la antigua base de datos en línea.

La sección Percorsi relaciona los contenidos con la actualidad, recordando efemérides en el formato de una timeline, y con artículos sobre acontecimientos o personalidades, ilustrados con fotografías, clips o galerías interactivas de imágenes. En la sección Servici, además de encontrar la información habitual, se describe y justifica pormenorizadamente la labor de documentación y catalogación llevada a cabo por el instituto.

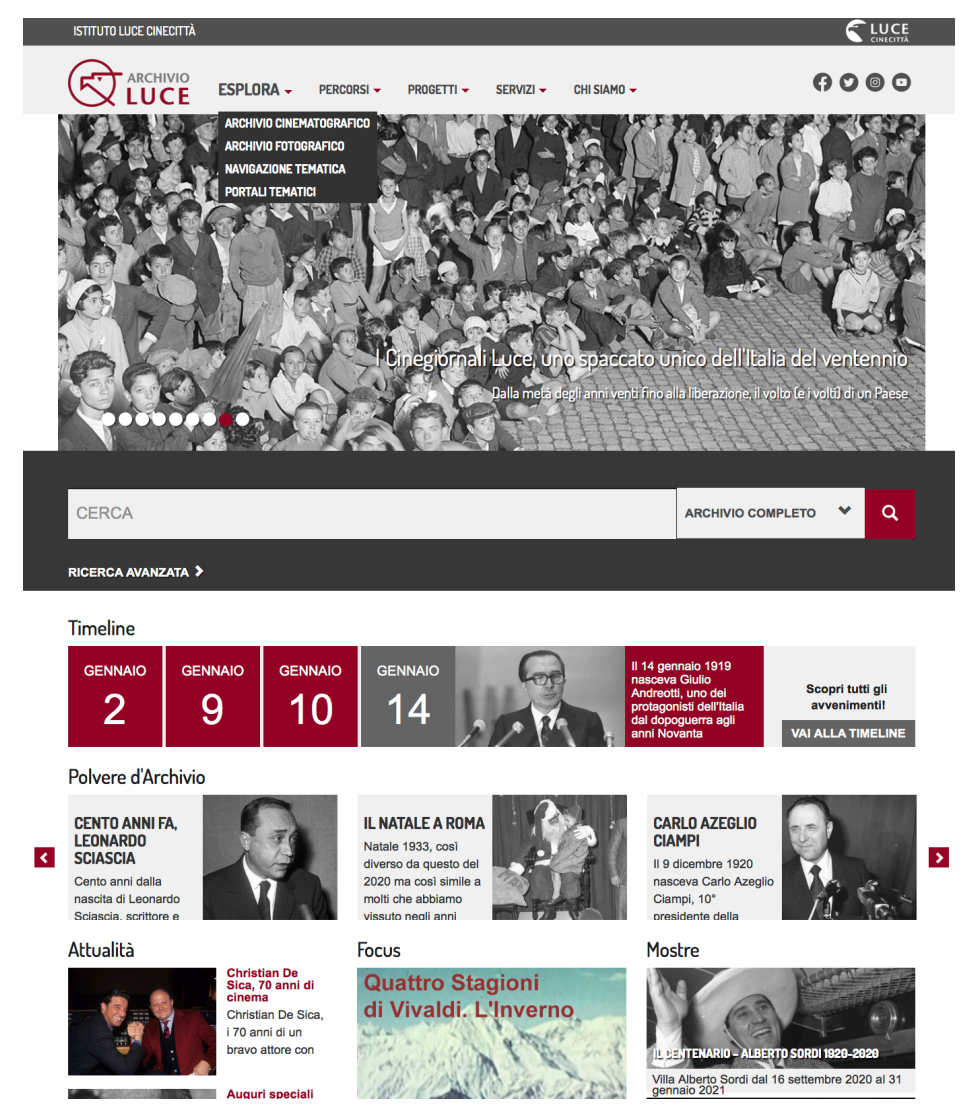

F7. Captura de la página de inicio de Archivio Storico Luce

Mediante galerías e imágenes interactivas, la página de inicio destaca muchas de las secciones accesibles a través del menú, incluyendo el acceso a la Navegazione temática. En lo alto del cuerpo de la página, una serie de 
diapositivas promocionan contenidos del archivo, noticias sobre exposiciones y artículos de actualidad realizados por el equipo de redacción de Luce.

En lo que concierne a la presentación de los noticiarios, observamos que, a excepción de algunos, como los primeros 49 números de Luce A, gran parte de ellos se encuentran disponibles. Archivio LUCE utiliza el reproductor de YouTube y los clips van acompañados de datos completos referidos tanto a la producción como al contenido, incluyendo una descripción de las secuencias. Además de utilidades similares a las de Gaumont Pathé o British Pathé, como la recuperación de contenidos mediante palabras clave divididas en las categorías - temas, personas y lugares-, botones para compartir y crear listas de preferencias mediante registro, se indican las restantes noticias del número del noticiario, lo cual permite contextualizar mejor los clips.

El Archivio Storico Luce está en Facebook ${ }^{25}$, Twitter ${ }^{26}$ e Instagram ${ }^{27}$, además de en YouTube ${ }^{28}$. El canal, creado en 2010, con unos 100.000 suscriptores, acumula más de 59 millones de visualizaciones. El vídeo de actualidades más popular, con más de 600 ooo visualizaciones, se titula "Mussolini e Hitler si incontrano a Monaco (1940)" (Istituto Luce Cinecittà, 2012). Tras una sucinta descripción sobre el contenido, sin la fecha, datos o indicaciones sobre el contexto histórico del encuentro, se indica la referencia del filme: Giornale Luce Coo51 del 25/06/1940. Aunque no hay un enlace directo a la página del vídeo en el archivo, con estos datos se puede localizar en el sitio web. Una breve presentación destaca la belleza y el carácter histórico del acervo: "tutte le immagini e i fotogrammi più belli di come eravamo, rivissuti attraverso i film, i documentari e i video che hanno fatto la storia del nostro Paese". Le siguen enlaces a Facebook, Twitter, al sitio oficial de Luce Cinecittà y a su tienda oficial.

\footnotetext{
25 https://www.facebook.com/ArchivioStoricoCinecittaLuce

${ }^{26} \mathrm{https}$ ://twitter.com/archivioluce

27 https://www.instagram.com/archivioluce

${ }_{28} \mathrm{https://www.youtube.com/c/istitutoluce}$
} 


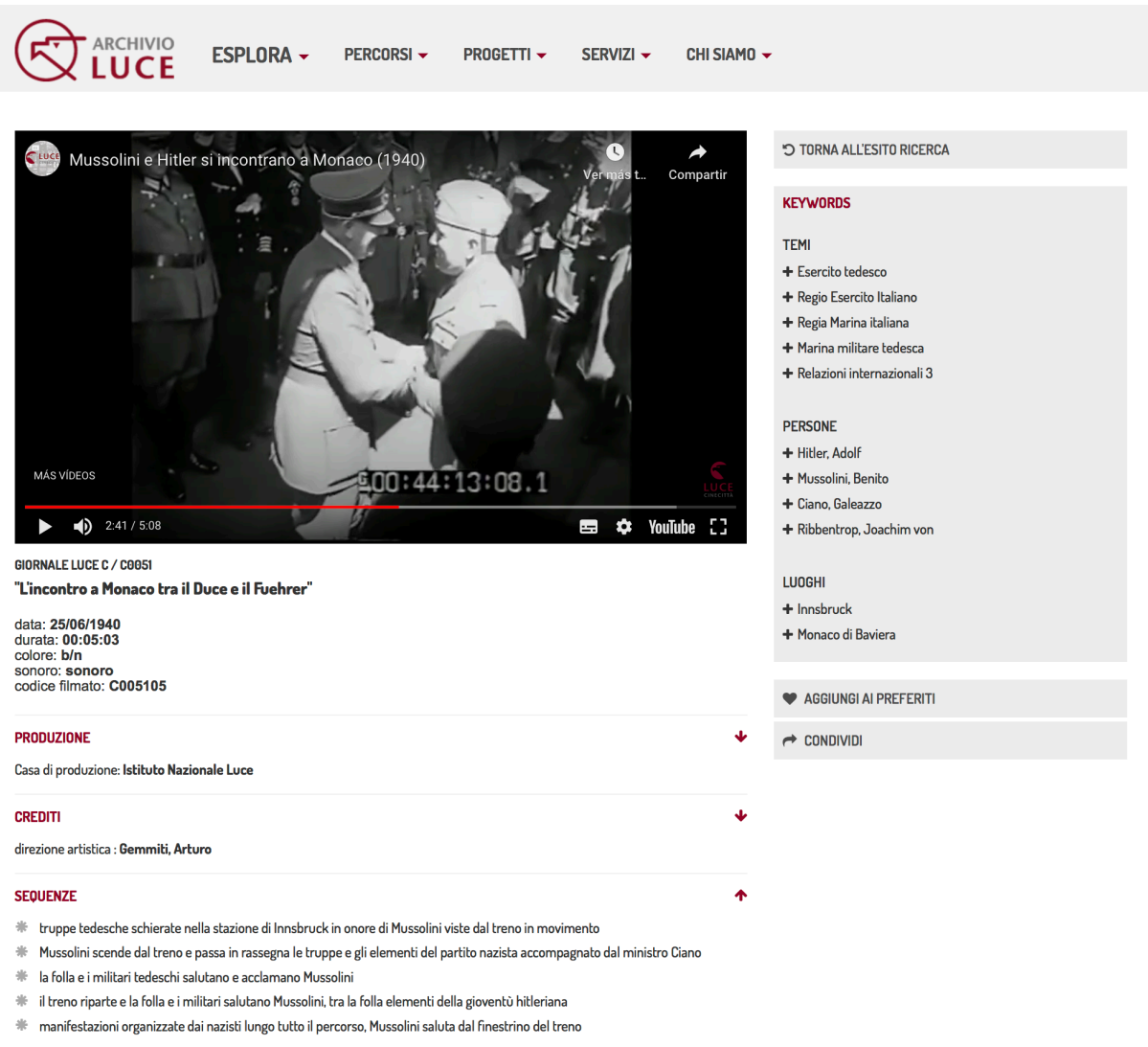

F8. Captura de una página del Archivio Storico Luce. Encuentro entre Mussolini y Hitler

Si bien la redacción del archivo realiza artículos sobre personalidades, acontecimientos y contenidos históricos en las secciones de su sitio, e ilustrados por los vídeos volcados en YouTube, desde el canal es difícil recuperarlos al no incluir hiperenlaces a los mismos, lo cual podría ayudar a una mejor contextualización. Pese a estas cuestiones, en general, en cuanto a la organización del sitio y al modo en el que se presentan sus contenidos, recursos y funcionalidades, consideramos que se trata de una web ejemplar de divulgación de patrimonio audiovisual.

\section{Conclusiones}

El análisis efectuado nos proporciona una perspectiva general de las principales características de estos sitios web de divulgación y comercialización de imágenes. 
La digitalización de los archivos trajo consigo la posibilidad de ampliar sus públicos, es decir, han traspasado la barrera de los profesionales del medio o de los investigadores y desarrollan estrategias al servicio de los intereses de sus diferentes usuarios. Un ejemplo de ello es el caso de British Pathé, que utiliza diferentes vías de comunicación con sus usuarios. Además de las redes sociales, su sitio ofrece otras posibilidades, de tal forma que el usuario puede aportar contenido al archivo comentando los vídeos o compartiendo sus propios catálogos. En consonancia con su carácter comercial, el sitio funciona como una tienda online en la que adquirir sus productos es fácil y rápido. En este sentido, las estrategias de valoración van ligadas también a las de promoción. En el sitio del Archivio Luce encontramos una tendencia similar de personalización de itinerarios, así como de expansión en las redes sociales, sobre todo al utilizar el reproductor de YouTube. Además de la preservación del patrimonio, Luce pretende fomentar y apoyar también su reutilización, por lo que estas estrategias le pueden servir para despertar el interés del público. En comparación, NO-DO, presentado como un repositorio abierto, no parece estar siguiendo ninguna fórmula actual de promoción, más allá de las de RTVE, sin dar continuidad a las realizadas en el momento de su lanzamiento en línea.

El eslogan "L'histoire du 2oème siècle, l'actualité du 21ème siècle" de la página oficial de Gaumont y Pathé, el primer ejemplo discutido aquí, parece referir que encontraremos imágenes tanto del pasado como contemporáneas, pero podemos interpretarlo también a la luz de lo que hemos observado. A pesar de las diferencias registradas, los casos analizados comparten un denominador común, ya que en todos existe un cuidado en promover el acervo a través de colecciones sugerentes que son organizadas acompañando la actualidad, es decir, el criterio de la agenda mediática es determinante. La efeméride suele ser la forma predilecta para la aproximación al pasado mediante formatos que van desde la organización de los contenidos en timelines hasta artículos ilustrados por vídeos o montajes de imágenes. Si hay un aspecto que los distingue como archivos en línea es la forma en como adaptan y presentan sus bases de datos en el entorno digital. Con respecto a esto, British Pathé y Luce 
aprovechan las herramientas digitales para ofrecer una experiencia de acceso más completa, útil para el periodista, realizador o investigador, pero también accesible a otros usuarios.

En sus textos de presentación, los archivos valoran la relevancia, la longevidad, la variedad y actualización de los fondos que los componen. Dicha actualización, más o menos constante, pretende, en primera instancia, atraer nuevos públicos y servir a sus intereses, pero también se utiliza para defender su estatus como lugares de memoria incontestables, de tal forma que sus sitios web se convierten en fuentes únicas y casi inagotables.

La insistencia en valorar el carácter histórico y patrimonial de las actualidades cinematográficas, junto con la de destacar su carácter singular, son dos argumentos en los que se reafirman para defender el acceso al pasado a través de sus imágenes. Si bien puede decirse que la información que ofrecen en la identificación, catalogación y documentación de estos recursos fílmicos es completa y pertinente, consideramos que la escasa contextualización de los mismos acaba por dar continuidad a la propia idiosincrasia de lo que fueron en el pasado. Estos filmes, que se encumbraron como registros de la actualidad, gracias a la tecnología del soporte fotoquímico, y medios de información, entretenimiento, propaganda y educación, con el desarrollo de los dispositivos de proyección, siempre mantuvieron una relación un tanto forzada y complementaria con la actualidad, debido a las propias características del medio cinematográfico y de su industria. Sin una mirada crítica, cuando la información complementaria se reduce a su contenido, el propio origen de los filmes acaba por determinar su conversión al presente, ya sea en populares y característicos contenidos de infoentretenimiento como curiosidades y desastres, ya sea en imágenes históricas desvinculadas de su contexto y finalidad propagandística. Igual que los noticiarios ofrecían una visión de la realidad que evitaba asuntos polémicos y controvertidos, inclinándose hacia la banalización, nos parece que los propios archivos parecen decantarse por una actualización del pasado poco crítica y que no los comprometa. En este sentido, habría que observar y analizar si esto se contrarresta mediante iniciativas y proyectos concretos como, por ejemplo, el 
de Luce per la Didattica, en el que el instituto se define por una vocación educativa que va más allá de la propaganda. En cualquier caso, sería pertinente que también la divulgación generalizada de este patrimonio fomentase su actualización y crítica desde el punto de vista histórico, mediático y fílmico.

Consideramos que la misión que realizan estas entidades es de crucial importancia para la conservación, documentación, digitalización, acceso y divulgación de su acervo, puesto que, sin ellas, estos filmes no gozarían de una nueva vida en el ecosistema efímero y mutable de internet. El potencial de estos recursos es inmenso, y no solo para la historia de las sociedades contemporáneas, sino también para el conocimiento de la evolución del cine y de los medios de comunicación. Si en el pasado los medios de masas nos desafiaron exigiéndonos nuevas alfabetizaciones y literacías, nos parece urgente cuestionar si al dar una larga vida a las actualidades cinematográficas se está aprovechando ese potencial de una forma reflexiva y crítica.

\section{Referencias bibliográficas}

Aubert, M. (1996). News before newsreel. En R. Smither, \& W. Klaue (Eds.), Newsreels in Film Archives: a survey based on the FIAF (pp. 22-25). Trowbridge, England: Flicks Books/ Associated University Presses.

Baechlin, P., \& Muller-Strauss, M. (1952). Newsreels across the world (trad. J. Beverridge). [PDF]. Paris: UNESCO. Recuperado de https://bit.ly/3j1Pgyu

Braga, R. (2005). Propaganda e representação de um país nas margens da guerra: o Jornal Português (1938-1951). (Tesis de máster, Universidad de Oporto, Portugal). [PDF] Recuperado de http://hdl.handle.net/10216/19329

British Pathé (s.f.). British Pathé. Recuperado de https://www.britishpathe.com

British Pathé (27 de julio de 2011). Hindenburg Disaster: Real Zeppelin Explosion Footage (1937) [Vídeo]. Recuperado de https://www.youtube.com/watch?v=CgWHbpMVQ1U

Cádima, F. (2020). A mémoria e a era digital. Media \& Jornalismo, 20(36), 193-206. https://doi.org/10.14195/2183-5462_36_10

Chambers, C., Jönsson, M., \& Winkel, R. V. (Eds.). (2018). Researching Newsreels. Local, National and Transnational Case Studies. Cham: Palgrave Macmillan. 
Codina, L., Pedraza, J., Díaz Noci, J., Rodríguez-Martínez, R., Pérez-Montoro, M, Cavaller-Reyes, V. (2014). Sistema Articulado de Análisis de Cibermedios (SAAC): una propuesta sobre el qué y el cómo para estudiar medios de comunicación digitales. Hipertext.net, 12. https://doi.org/10.2436/20.8050.01.13

Coronado Ruiz, C. (2016). El cine informativo: ¿El arma más fuerte? La recepción de los noticiarios cinematográficos "Luce" durante el fascismo. Área Abierta, 16(3), 51-65. https://doi.org/10.5209/ARAB.53657

Cuadra de la, E. (2005). British Pathé: análisis de la página web de un archivo fílmico. Cuadernos De Documentación Multimedia, 16, 43-51. Recuperado de https://bit.ly/2XloqoQ

Domínguez Delgado, R., \& López Hernández, M. A. (2016). Film content analysis at six major Spanish film libraries. El profesional de la información, 25(5), 787-794. https://doi.org/10.3145/epi.2016.sep.09

Domínguez Delgado, R., \& López Hernández, M. Á. (2017a). Film content analysis on FIAF cataloguing rules and CEN metadata standards. En S. Erdelez \& N.K. Agarwal (Eds.), Proceedings of the Association for Information Science and Technology (pp. 655- 657.) Hoboken, NJ: Wiley. https://doi.org/10.1002/pra2.2017.14505401104

Domínguez-Delgado, R. \& López Hernández, M. A. (2017b). Una perspectiva histórica del análisis documental de contenido fílmico. Documentación de las Ciencias de la Información, 40, 73-90. https://doi.org/10.5209/DCIN.56621

Eiroa, M., \& Barranquero, A. (2017). Métodos de investigación en la comunicación y sus medios. Madrid: Síntesis.

Federación Internacional de Archivos Fúlmicos. (2009). FIAF Technical Commission preservation best practice. [PDF]. Recuperado de https://bit.ly/2FTXY3k

Ferro, M. (1993). Cinéma et Histoire [Nouvelle édition refondue]. Paris: Gallimard.

Gaumont Pathé Archives. (s.f.). GP Archives. Actualités-Documentaires. Recuperado de https://gparchives.com/index.php?html=4

Hiley, N., \& McKernan, L. (2001). Reconstructing the News: British newsreel documentation and the British Universities Newsreel Project. Film History, 13(2), 185-199.

Huret, M. (1984). Ciné Actualités. Histoire de la Presse Filmée 1895-1980. Paris: Henri Veyrier.

Istituto Luce-Cinecittà (s.f.). Archivio storico Istituto Luce. Recuperado de https://www.archivioluce.com

Istituto Luce-Cinecittà (12 de junio de 2012). Mussolini e Hitler si incontrano a Monaco (1940) [Vídeo]. Recuperado de https://www.youtube.com/watch?v=GHey62VGE2k 
Johnson, M. (2013). The revolution will be archived: Cuba's Noticiero ICAIC Latinoamericano. The Moving Image: The Journal of the Association of Moving Image Archivist, 13 (2), 1-21. https://doi.org/10.5749/movingimage.13.2.0001

Kaye, L. (2018). If you build it, will they come? Researching British newsreels. En C. Chambers, M. Jönsson, \& R. V. Winkel (Eds.), Researching Newsreels. Local, national and transnational case studies (pp. 285300). Cham: Palgrave Macmillan.

Kracauer, S. (1943). The Conquest of Europe on the Screen: The Nazi Newsreel, 1939-40. Social Research, 10 (3), 337-357. Recuperado de https://www.jstor.org/stable/40981970

Lenhert, S. (2018). Advertising and Self-Reference in the West German Newsreel Neue Deutsche Wochenschau in the 1950s and 1960s. En C. Chambers, M. Jönsson, \& R. V. Winkel (Eds.), Researching Newsreels. Local, national and transnational case studies (pp. 203-230). Cham: Palgrave Macmillan.

Lehnert, S. (2020). (Re-)presentation of Everyday Heroes in German Post-war Newsreels (West-East). Akademisk Kuarter, 20, 154-173. https://doi.org/10.5278/ojs.academicquarter.vi20.5854

Lobo, J. Ramos, J., \& Antunes, M. J. (2020). Digital Platforms Audiovisual Culture and Memory: the Case of Film Festivals in the North and Northeast of Brazil. Journal of Digital Media \& Interaction, 3 (7), 111123. https://doi.org/10.34624/jdmi.v3i7.15541

Lusnich, A. L., \& Morettin, E. (2020). El cine y la memoria: formas de producción y dimensiones históricas. Fotocinema, 20, 3-13. https://doi.org/10.24310/Fotocinema.2020.v20i1.7587

MacKay, J. (2018). Matrices for Non-Fiction: Dziga Vertov and the KinoNedelia Newsreels. En C. Chambers, M. Jönsson, \& R. V. Winkel (Eds.), Researching Newsreels. Local, National and Transnational Case Studies (pp. 119-141). Cham: Palgrave Macmillan.

Martins, A. (2020). Antes do filme, a Revolução: o caso do Jornal Cinematográfico Nacional (1975-1977). (Tesis doctoral, Universidad de Huelva, España). [PDF] Recuperado de http://www.doctoradocomunicacion.es/tesis.php

Martins, A., Novoa Fernández, O., Aguaded, I., \& Tavares, M. (2019). It's online, it's news: appropriation of viral narratives by the digital press. Journal of Science and Technology of the Arts, 11(1), 61-68. https://doi.org/10.7559/citarj.v11i1.597

Matos-Cruz de, J. (1989). Prontuário do Cinema Português 1896-1989. Lisboa: Cinemateca Portuguesa.

McKernan, L. (1992). The Great Britain News Film. Topical-Budget. London: British Film Institute. 
McKernan, L. (12 de febrero de 2017). Newsreels and history. XI Jornadas de Investigação do CIAC. [Entrada de blog]. Recuperado de https://bit.ly/2EzFhS6

McKernan, L. (2009). Newsreels: form and function. En R. Howells \& R. Matson, Using visual evidence (pp. 95-106). Maidenhead, Berkshire: Open University Press/McGraw-Hill.

Morettin, E. V. (2014). Acervos cinematográficos e pesquisa histórica: questões de método. Revista Esboços, 21 (31), 50-67. http://dx.doi.org/10.5007/2175-7976.2014v21n31p50

Müller, E. (2018) 'Great Stuff!': British Pathé's YouTube Channel and Curatorial Strategies for Audiovisual Heritage in a Commercial Ecosystem. VIEW Journal of European Television History and Culture, 7(13), 19-30. $\quad$ http://doi.org/10.18146/22130969.2018.jethc139

Novoa Fernández, O. (2019). Noticiarios enlatados: del rescate a la literacía de las imágenes referentes a España en el cine informativo portugués. (Tesis doctoral, Universidad del Algarve, Portugal). [PDF]. Recuperado de http://hdl.handle.net/10400.1/13631

Nichols, B. (1972). Newsreeel: film and revolution. (Tesis de Máster, Universidad de California, Los Ángeles, Estados Unidos). [PDF]. Recuperado de https://bit.ly/3hUvB28

Nichols, B. (1978). Newsreel: documentary filmmaking on the american left (1971-1975). (Tesis doctoral, Universidad de California, Los Ángeles, Estados Unidos). [PDF]. Recuperado de https://bit.ly/309fqrM

Paz, M. A., \& Montero, J. (1999). Creando la realidad. El cine informativo 1895-1945. Barcelona: Ariel.

Piçarra, M. C. (2006). Salazar vai ao cinema. O Jornal Português de actualidades filmadas. Coimbra: MinervaCoimbra.

Pontecorvo, L. (1983). What is newsreel? En J. Ballantyne (Ed.), Researcher's Guide to British Newsreels (pp. 6-7). London: Universities Film \& Video Council.

Radio Televisión Española \& Filmoteca Española. (s. f.). Archivo Histórico del NO-DO. Recuperado de https://www.rtve.es/filmoteca/no-do/

Reia-Baptista, V. (2010). Lenguajes fílmicos en la memoria colectiva de Europa. Comunicar, 35, 10-13. https://doi.org/10.3916/C35-2010-02$\underline{\mathrm{OO}}$

Rodríguez Martínez, R., Codina, L., \& Pedraza Jiménez, R. (2012). Indicadores para la evaluación de la calidad en cibermedios: análisis de la interacción y de la adopción de la Web 2.0. Revista Española de Documentación Científica, $\quad 35(1), \quad 61-93$. http://dx.doi.org/10.3989/redc.2012.1.858

Rodríguez Mateos, A. (2008). Un franquismo de cine. La imagen política del Régimen en el noticiario NO-DO (1943-1959). Madrid: RIALP 
Sánchez-Biosca, V. (2015). Exploración, experiencia y emoción de archivo. A modo de introducción. Aniki, 2 (2), 220-223. http://dx.doi.org/10.14591/aniki.v2n2.190

Schefer, R. (2016). El retorno del newsreel (2011-2016) en las representaciones fílmicas contemporáneas del acontecimiento político. Cinema Comparat/ive Cinema, 9 (4), 62-71. Recuperado de https://bit.ly/331CjPD

Shpolberg, M. (2014). The din of gunfire: Rethinking the role of sound in World War II newsreels. NESCUS. European Journal of Media Studies, 3(2), 113-127. https://doi.org/10.5117/NECSUS2014.2.SHPO

Sieber, S. (2016). The politics of archives. Media, power, and identity. Em K. Imesch, S. Schade, S. Sieber (Eds.), Constructions of Cultural Identities in Newsreel Cinema and Television after 1945 (pp. 21-38). Recuperado de https://www.jstor.org/stable/j.ctv1wxt68.4

Smither, R., \& Klaue, W. (Eds.) (1996). Newsreels in Film Archives: a survey based on the FIAF Newsreel Symposium. Trowbridge: Flicks Books/Associated Universities Presses.

Sorlin, P. (1994). Italian cinema's rebirh, 1937-1943: a paradox of Fascism. Historical Journal of Film, Radio and Television, 14(1), 3-14. https://doi.org/10.1080/01439689400260011

Sorlin, P. (2004). The French newsreels of the First World War. Historical Journal of Film, Radio and Television, 24(4), 507-515. https://doi.org/10.1080/0143968042000293847

Torrado Morales, S. (2005). Análisis comparativo de las web de las filmotecas españolas en Internet. Cuadernos de documentación multimedia, 16. 11-20. Recuperado de https://bit.ly/2S2SW73

Torrado Morales, S. (2007). La página web del archivo histórico del instituto Luce: un instrumento de difusión cinematográfica. Anales De Documentación, 10, 413-428. Recuperado de https://bit.ly/363ruhM

Tranche, R. R., \& Sánchez-Biosca, V. (2006). NO-DO. El tiempo y la memoria (8. ${ }^{\mathrm{a}}$ ed.). Madrid: Cátedra/Filmoteca Española.

Túñez López, M., \& Chillón Ávarez, A. (2010). Difusión de la cultura en Internet: mapa mundial de las plataformas online. Fonseca Journal of Communication, 1, 124-149. Recuperado de https://bit.ly/2HmcEIW 